\title{
Re-Challenging Taxanes in Recurrent Breast Cancer in Patients Treated with (Neo-)Adjuvant Taxane-Based Therapy
}

\author{
Xinrong Guo ${ }^{a}$ Sibylle Loibl ${ }^{\mathrm{a}} \quad$ Michael Untch $^{\mathrm{b}}$ Volker Möbus $^{\mathrm{c}} \quad$ Kathrin Schwedler $^{\mathrm{d}}$ \\ Peter A. Fasching ${ }^{\mathrm{e}}$ Jana Barinoff ${ }^{f}$ Frank Holms $^{g}$ Christoph Thomssen ${ }^{\mathrm{h}}$ Dirk M. Zahm ${ }^{\mathrm{i}}$ \\ Rolf Kreienberg ${ }^{\mathrm{k}}$ Maik Hauschild Holger Eidtmann $^{\mathrm{m}}$ Sascha Tauchert ${ }^{\mathrm{n}}$ Keyur Mehta ${ }^{\mathrm{a}}$ \\ Gunter von Minckwitz ${ }^{a}$ for the German Breast Group and AGO-B Study Group \\ ${ }^{a}$ German Breast Group, ${ }^{b}$ Helios Klinikum Berlin-Buch, ${ }^{\circ}$ Frauenklinik, Klinikum Frankfurt-Höchst, dUniversitäts-Frauenklinik Frankfurt, \\ ${ }^{e}$ Frauenklinik des Universitätsklinikums Erlangen, Friedrich-Alexander Universität Erlangen-Nürnberg, Erlangen,

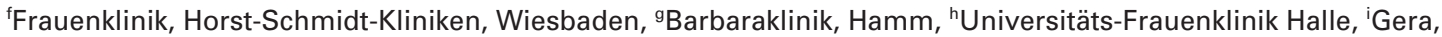

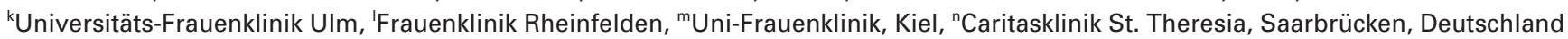

\section{Keywords}

Docetaxel · Paclitaxel · Adjuvant · Recurrent breast cancer

\section{Summary}

Background: Docetaxel and paclitaxel are among the most active substances for the treatment of breast cancer. As both drugs are used today in adjuvant regimens, efficacy data from pivotal trials in the metastatic setting in taxanenaive populations cannot reliably be used as references. Patients and Methods: The Taxane Re-Challenge Cohort Study identified participants from 6 prospective (neo-)adjuvant taxane-based studies with recurrent disease and collected data on their subsequent treatment. Out of 381 recurrent patients, $106(27.8 \%)$ were re-challenged with a taxane-based treatment as first- or later-line therapy for recurrent disease. Results: Taxanes were used as first-line therapy in 74 patients and showed a response rate of $48.6 \%$ (including complete responses in $27.0 \%$ ). The response rate was dependent on the disease-free interval $(<1$ year: $34.8 \%$; $1-2$ years: $42.9 \%$; $>2$ years: $63.3 \% ; p=0.04)$ and visceral metastasis (present: 62.5\%; not present $32.4 \%$; $p=0.01$ ). Patients without visceral metastasis and with a disease-free interval of $>2$ years achieved the longest overall survival. Hormone and HER2 receptor status were not predictive; however, triple-negative tumors responded in $50.0 \%$. The overall response rate of later-line taxane-based treatment was $28.2 \%$. Conclusion: Re-challenging taxanes appears to be effective and therefore represents a reasonable option in this population.

\section{Schlüsselwörter \\ Docetaxel · Paclitaxel · Adjuvant · Rezidivierter Brustkrebs}

\section{Zusammenfassung}

Hintergrund: Docetaxel und Paclitaxel gehören zu den aktivsten Substanzen in der Behandlung des Mammakarzinoms. Da sie heute häufig bereits zur adjuvanten Behandlung eingesetzt werden, können Effektivitätsdaten von früheren Studien mit Taxan-naiven, metastasierten Patientinnen nicht mehr als zuverlässig angesehen werden. Patienten und Methoden: Für die Taxane Re-Challenge Kohortenstudie haben wir Teilnehmerinnen 6 prospektiver Taxanbasierter (neo-)adjuvanter Studien mit rezidivierter Erkrankung identifiziert und Daten zur weiteren Behandlung gesammelt. Bei 106 (27,8\%) von 381 Patientinnen mit einem Rezidiv oder einer Metastase wurde erneut ein Taxan in der ersten oder späteren Behandlung eingesetzt. Ergebnisse: Taxane wurden in der Erstlinie bei 74 Patientinnen angewandt und zeigten eine Ansprechrate von $48,6 \%$ (inklusive Komplettremissionen in 27,0\%). Die Ansprechrate war vom krankheitsfreien Intervall (<1 Jahr: 34,8\%; 1-2 Jahre: 42,9\%; $>2$ Jahre: $63,3 \% ; p=0,04)$ und dem Vorhandensein viszeraler Metastasen (vorhanden: 62,5\%; nicht vorhanden: 32,4\%; $\mathrm{p}=0,01$ ) abhängig. Patientinnen ohne viszerale Metastasen und mit einem krankheitsfreien Intervall $>2$ Jahre überlebten am längsten. Hormon- und HER2-Rezeptorstatus waren für das Ansprechen nicht prädiktiv, jedoch sprachen tripelnegative Tumoren in $50.0 \%$ auf die erneute Taxan-Therapie an. Die Gesamtansprechrate auf ein erneutes Taxan in der späteren Linie betrug 28.2\%. Schlussfolgerung: Der Wiedereinsatz von Taxanen erscheint effektiv und steht somit als sinnvolle Option für mit Taxanen (neo-)adjuvant vorbehandelte Patientinnen zur Verfügung.

\section{KARGER \\ Fax +497614520714 \\ Information@Karger.de}

www.karger.com
(C) 2011 S. Karger GmbH, Freiburg

$1661-3791 / 11 / 0064-0279 \$ 38.00 / 0$

Accessible online at:

www.karger.com/brc
Prof. Dr. Gunter von Minckwitz

German Breast Group

c/o GBG Forschungs GmbH

Martin-Behaim-Str. 12, 63263 Neu-Isenburg, Germany

Tel. +49 6102 7480-411, Fax -111

Gunter.vonMinckwitz@germanbreastgroup.de 


\section{Introduction}

Taxanes (docetaxel, paclitaxel, nab-paclitaxel) are among the most active substances for the treatment of breast cancer. Overall response rates of $25-69 \%$ have been reported when taxanes are used as first-line-treatment of metastatic breast cancer in taxane-naive patients [1-3]. However, as a consequence of the increase in the use of taxanes as therapy for early-stage breast cancer [4], more patients presenting with metastatic disease have been pretreated with taxanes. There is an almost complete lack of data as to how far the efficacy reported for taxanes in the pivotal trials remains stable with this change. First, patients relapsing despite having received (neo-)adjuvant taxane-based treatment might have more aggressive tumors, and second, metastasis of these tumors might be resistant to taxanes. Despite this lack of evidence, current guidelines recommend a re-introduction of a taxane for metastatic disease only after a treatment-free period of 1 year [5].

The Taxane Re-Challenge Cohort Study was conducted to determine the efficacy of taxane-based treatment as first-line or later-line therapy for recurrent or metastatic breast cancer in participants of (neo-)adjuvant taxane-containing chemotherapy trials.

\section{Patients and Methods}

Study Design

The Taxane Re-Challenge Cohort Study collected retrospectively data on treatment, efficacy, and outcome of patients with recurrent disease from 6 large-scale, multi-centric, prospective (neo-)adjuvant chemotherapy trials conducted in Germany between 1999 and 2008.

\section{Objectives}

Objectives of this study were the overall (complete and partial) response rate of first- and later-line taxane-based treatment, overall survival after relapse, to find the predictors for a better efficacy, and to determine the efficacy specifically in the subgroup of patients with triple-negative tumors.

\section{Patient Characteristics}

Eligible patients were identified from the study databases of the adjuvant or neoadjuvant trials of the German Breast Group and the Arbeitsgemeinschaft Gynäkologische Onkologie (AGO) Breast Study Group [6-15]. All of them had been treated with either docetaxel or paclitaxel as part of their primary treatment (adjuvant or neoadjuvant chemotherapy) and had had a local or distant relapse reported. Overall, information on 381 out of 1100 patients with recurrent or metastatic breast cancer was received, representing $34.6 \%$ of all identified patients. 106 patients $(27.8 \%)$ of those, from 41 centers, had received taxane-based treatment as first- or later-line therapy and were analyzed in this study.

\section{Statistical Analysis}

The primary objective of this trial was to show adequate activity of taxane retreatment measured by the objective response rate. Efficacy analysis was performed on the whole population; unavailable responses were considered as treatment failures. Response rates were compared using chi-square tests. Overall survival time was analyzed using Kaplan-Meier estimates. The log-rank test was used to test for differences between overall survival curves. Values of $\mathrm{p}<0.05$ were considered to be statistically significant. The data were analyzed using SPSS version 14.0 (SPSS Inc., Chicago, IL, USA).

\section{Results}

\section{Patient Characteristics}

A total of 106 patients who received taxane-based treatment as first- or later-line therapy were enrolled in this cohort study. The median age of the patients was 48 (25-77) years. The baseline characteristics of all patients are given in table 1. 74 patients received re-challenge with a taxane as first-line treatment and 39 patients received taxane re-challenge at a later line ( 7 patients received both). First-line taxane treatment was given in combination in 44 patients, i.e. with anthracyclines $(n=27)$, capecitabine $(n=13)$, trastuzumab $(n=13)$, bevacizumab $(\mathrm{n}=11)$, platinum compounds $(\mathrm{n}=7)$, gemcitabine $(n=4)$, and vinorelbine $(n=2)$. The most frequently used regimens were docetaxel or paclitaxel with doxorubicin and cyclophosphamide. Monotherapy with paclitaxel was given to 17 patients and with docetaxel to 13 patients.

\section{Efficacy and Outcome of Taxane Re-Challenge as First-Line Therapy}

The overall response rate in 74 patients receiving re-challenge with taxanes as first-line treatment was $48.6 \%$, consisting of $20(27.0 \%)$ complete and $16(21.6 \%)$ partial remissions. The

Table 1. Baseline characteristics of 106 patients re-challenged with taxanes as treatment for recurrent disease

\begin{tabular}{|c|c|}
\hline Parameter & $\mathrm{n}(\%)$ \\
\hline \multicolumn{2}{|l|}{ Age, years } \\
\hline$<50$ & $60(56.6)$ \\
\hline $50-69$ & $45(42.5)$ \\
\hline$>70$ & $1(0.9)$ \\
\hline \multicolumn{2}{|l|}{$\mathrm{ER} / \mathrm{PgR}$ status } \\
\hline Positive & $54(50.9)$ \\
\hline Negative & $44(41.5)$ \\
\hline Unknown & $8(7.6)$ \\
\hline \multicolumn{2}{|l|}{ HER2 status } \\
\hline Positive & $22(20.8)$ \\
\hline Negative & $62(58.5)$ \\
\hline Unknown & $22(20.7)$ \\
\hline \multicolumn{2}{|c|}{ Triple (ER/PgR/HER2)-negative status } \\
\hline Yes & $29(27.4)$ \\
\hline No & $49(46.2)$ \\
\hline Unknown & $28(26.4)$ \\
\hline \multicolumn{2}{|c|}{ Taxane type as (neo-)adjuvant chemotherapy } \\
\hline Docetaxel & $54(50.9)$ \\
\hline Paclitaxel & $52(49.1)$ \\
\hline \multicolumn{2}{|c|}{ Chemotherapy setting } \\
\hline Neoadjuvant & $81(76.4)$ \\
\hline Adjuvant & $25(23.6)$ \\
\hline \multicolumn{2}{|c|}{ Disease-free-survival until recurrence } \\
\hline$<1$ year & $28(26.4)$ \\
\hline $1-2$ years & $30(28.3)$ \\
\hline$>2$ years & $48(45.3)$ \\
\hline \multicolumn{2}{|c|}{ Visceral metastasis } \\
\hline Yes & $47(44.3)$ \\
\hline No & $59(55.7)$ \\
\hline
\end{tabular}


Table 2. Clinical response to first-line taxane-based therapy

\begin{tabular}{lcclrr}
\hline First-line therapy & CR, $\mathrm{n}(\%)$ & PR, $\mathrm{n}(\%)$ & $\mathrm{SD}, \mathrm{n}(\%)$ & $\mathrm{PD}, \mathrm{n}(\%)$ & Response unknown, $\mathrm{n}(\%)$ \\
\hline All $(\mathrm{n}=74)$ & $20(27.0)$ & $16(21.6)$ & $4(5.4)$ & $15(20.3)$ & $19(25.7)$ \\
Docetaxel $(\mathrm{n}=39)$ & $6(15.4)$ & $9(23.1)$ & $4(10.3)$ & $10(25.6)$ & $10(25.6)$ \\
Paclitaxel $(\mathrm{n}=35)$ & $14(40.0)$ & $7(20.0)$ & $0(0)$ & $5(14.3)$ & $9(25.7)$ \\
Monotherapy (n=30) & $6(20.0)$ & $6(20.0)$ & $1(3.3)$ & $7(23.3)$ & $10(33.3)$ \\
Combination therapy $(\mathrm{n}=44)$ & $14(31.8)$ & $10(22.7)$ & $3(6.8)$ & $8(18.2)$ & $9(20.5)$ \\
\hline
\end{tabular}

$\mathrm{CR}=$ Complete response, $\mathrm{PR}=$ partial response, $\mathrm{SD}=$ stable disease; $\mathrm{PD}=$ progressive disease.

Table 3. Univariable analysis on response to first-line-therapy and overall survival according to patient characteristics

\begin{tabular}{|c|c|c|c|c|c|}
\hline Parameter & Patients, $\mathrm{n}$ & $\mathrm{CR} / \mathrm{PR}, \mathrm{n}(\%)$ & $\mathrm{Chi}^{2}, \mathrm{p}$ & $\begin{array}{l}\text { Median overall sur- } \\
\text { vival, years }(95 \% \mathrm{CI})\end{array}$ & Log rank, $p$ \\
\hline \multicolumn{6}{|l|}{ Age } \\
\hline$<50$ & 40 & $21(52.5 \%)$ & & $1.4(0.5-2.3)$ & \\
\hline$\geq 50$ & 34 & $15(44.1 \%)$ & $>0.1$ & $1.3(0.5-2.1)$ & $>0.1$ \\
\hline \multicolumn{6}{|l|}{$\mathrm{ER} / \mathrm{PgR}$ status } \\
\hline Positive & 37 & $19(51.4 \%)$ & & $1.5(0.4-2.6)$ & \\
\hline Negative & 32 & $15(46.9 \%)$ & $>0.1$ & $1.3(0.8-1.8)$ & $>0.1$ \\
\hline \multicolumn{6}{|l|}{ HER2 status } \\
\hline Positive & 11 & $7(63.6 \%)$ & & $4.0(1.9-6.1)$ & \\
\hline Negative & 50 & $26(52.0 \%)$ & $>0.1$ & $1.3(0.9-1.7)$ & $>0.1$ \\
\hline \multicolumn{6}{|c|}{ Triple (ER/PgR/HER2)-negative status } \\
\hline Yes & 24 & $12(50.0 \%)$ & & $1.4(0.4-2.4)$ & \\
\hline No & 33 & $19(57.6 \%)$ & $>0.1$ & $1.5(0.4-2.4)$ & $>0.1$ \\
\hline \multicolumn{6}{|c|}{ Taxane as (neo-)adjuvant chemotherapy } \\
\hline Docetaxel & 39 & $19(48.7 \%)$ & & $1.3(1.0-1.6)$ & $>0.1$ \\
\hline Paclitaxel & 35 & $17(48.6 \%)$ & $>0.1$ & $1.2(0.0-2.5)$ & \\
\hline \multicolumn{6}{|c|}{ Disease-free interval until recurrence } \\
\hline$\leq 2$ years & 44 & $17(38.6 \%)$ & & $0.9(0.7-1.1)$ & 0.002 \\
\hline$>2$ years & 30 & $19(63.3 \%)$ & 0.04 & $4.0(1.9-6.1)$ & \\
\hline \multicolumn{6}{|c|}{ Visceral metastasis } \\
\hline Present & 40 & $25(62.5 \%)$ & & $1.0(0.7-1.4)$ & \\
\hline Not present & 34 & $11(32.4 \%)$ & 0.01 & $2.4(1.1-3.7)$ & 0.04 \\
\hline \multicolumn{6}{|c|}{ Taxane as first-line therapy } \\
\hline Docetaxel & 39 & $15(38.5 \%)$ & & $2.4(1.1-3.7)$ & \\
\hline Paclitaxel & 35 & $21(60.0 \%)$ & 0.06 & $1.0(0.5-1.4)$ & $>0.1$ \\
\hline
\end{tabular}
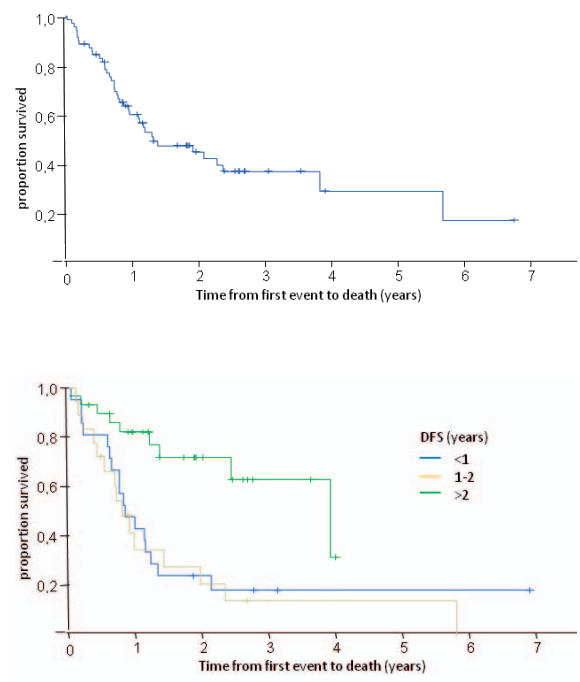

Fig. 1. Overall survival of patients receiving taxane re-challenge as firstline therapy.

Fig. 2. Overall survival of patients receiving taxane re-challenge as firstline therapy according to the length of the diseasefree interval.
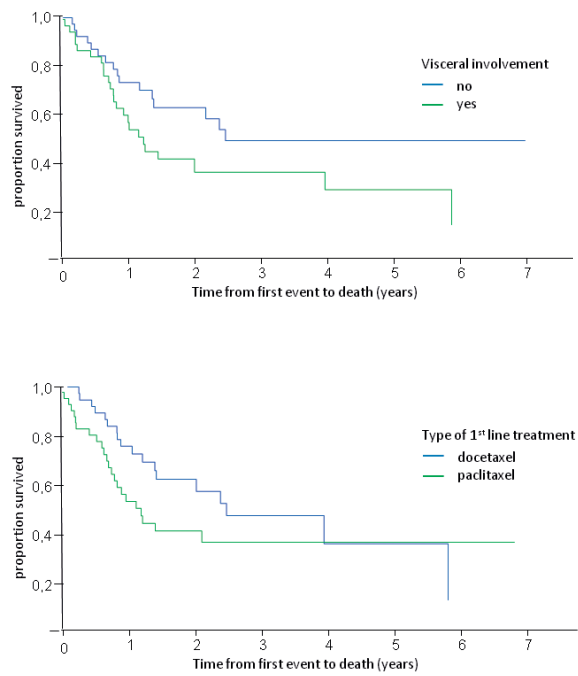

Fig. 4. Overall survival of patients receiving taxane rechallenge as first-line therapy according to the type of taxane used in this setting.

overall response rate was $54.5 \%$ with combination therapy and $40 \%$ with taxane monotherapy $(\mathrm{p}=0.2)$ (table 2$)$. Patients with a disease-free interval of $<1$ year until recurrence showed a response rate of $34.8 \%$, those with $1-2$ years, a rate of $42.9 \%$, compared to those with $>2$ years having a response rate of $63.3 \%(p=0.04)$. Other factors influencing the re-

sponse rate were the presence of visceral metastasis $(\mathrm{p}=0.01)$ and the type of taxane used $(\mathrm{p}=0.06)$, whereas age, type of taxane used for (neo-)adjuvant treatment, and hormone and HER2 receptor status were not predictive (table 3 ). However, there was no difference in response rates in relation to the type of taxane that was used for re-challeng (table 2). 
Table 4. Clinical response to later-line taxane-based therapy

\begin{tabular}{llclll}
\hline Later-line therapy & $\mathrm{CR}, \mathrm{n}(\%)$ & $\mathrm{PR}, \mathrm{n}(\%)$ & $\mathrm{SD}, \mathrm{n}(\%)$ & $\mathrm{PD}, \mathrm{n}(\%)$ & Response unknown, $\mathrm{n}(\%)$ \\
\hline Docetaxel $(\mathrm{n}=13)$ & $0(0.0)$ & $2(15.4)$ & $1(7.7)$ & $2(15.4)$ & $8(61.5)$ \\
Paclitaxel $(\mathrm{n}=26)$ & $1(3.8)$ & $8(30.8)$ & $8(30.8)$ & $2(7.7)$ & $7(26.9)$ \\
All $(\mathrm{n}=39)$ & $1(2.6)$ & $10(25.6)$ & $9(23.1)$ & $4(10.3)$ & $15(38.5)$ \\
\hline
\end{tabular}

$\mathrm{CR}=$ Complete response, $\mathrm{PR}=$ partial response, $\mathrm{SD}$ = stable disease; $\mathrm{PD}=$ progressive disease.

The median overall survival of these patients was 1.3 years (fig. 1). It was longer in patients with a disease-free interval of $>2$ years (median overall survival (in years) for diseasefree interval of $<1$ year: 0.9 ; $1-2$ years: 0.9 ; $>2$ years: 4.0 ; $\mathrm{p}=0.002$ ) (table 3 , fig. 2) and in patients without visceral metastasis (visceral metastasis present: 1.0 year; not present: 2.4 years; $p=0.04$ ) (table 3, fig. 3). Patients treated with docetaxel as first-line treatment showed a trend towards a longer overall survival of 2.4 years compared to those treated with paclitaxel (1.0 year) $(\mathrm{p}=0.1)$ (table 3 , fig. 4$)$.

\section{Efficacy of Taxane Re-Challenge at a Later Line}

A total of 39 patients were treated with a taxane for recurrent disease as later-line therapy. The median number of preceding regimens for metastatic disease was 3 (range 1-18). The overall response rate of later-line taxane-based treatment was $28.2 \%$. The overall response rate with docetaxel was $15.4 \%$ and with paclitaxel $34.6 \%$ (table 4 ). There were 7 patients who received taxane-based treatment as first-line and laterline therapy. With these 7 patients, the best response to the first-line therapy was 1 complete response, and the overall response was $47.1 \%$, (1 (14.3\%) complete and $3(42.9 \%)$ partial responses); the best response to later-line therapy was $1(14.3 \%)$ disease stabilization.

\section{Discussion}

There is an increasing number of patients with metastatic breast cancer who are pretreated with taxanes in the (neo-) adjuvant situation. Therefore, it is essential to re-assess the efficacy of taxane-based treatment in this group of patients.

In this retrospective multicenter cohort study, we observed an overall response rate of $48.6 \%$, consisting of $27.0 \%$ complete and $21.6 \%$ partial responses, with a median overall survival of 1.3 years in patients who received taxane-based treatment as first-line therapy. The response rate using taxane monotherapy was $40 \%$, and using combination therapy, $54.5 \%$. This is in the range of what was observed in trials including taxane-naive patients. 5 multicenter phase II trials for first-line treatment of metastatic breast cancer with docetaxel monotherapy of 75 or $100 \mathrm{mg} / \mathrm{m}^{2}$ reported an overall response rate between 38 and $68 \%$ and a median overall survival of 16.4 months across these studies [16], and a phase III study assessing docetaxel and doxorubicin reported a response rate of $48 \%$ [17]. Docetaxel in combination with doxorubicin, doxorubicin/cyclophosphamide, and trastuzumab reached response rates of 59,61 , and $77 \%$, respectively [18-20]. The response rate of paclitaxel monotherapy is largely dependent on dosing, infusion time and scheduling, and ranged between 22 and $62 \%[21,22]$. Combination of paclitaxel with doxorubicin as well as trastuzumab were highly effective, with response rates of 94 and $50 \%$, but the former was associated with significant cardiotoxicity [23, 24].

The observed response rates with re-challenging a taxane appear higher than those with capecitabine, vinorelbine or ixabepilone in a similar setting, which were usually in the range of $20-30 \%$ [25].

The strongest predictors for the effect of taxane re-challenge were the presence of visceral metastasis and the duration of the disease-free interval. The observed higher response rate in patients with a longer disease-free interval can be explained by the assumption that tumors with high resistance to taxanes recur earlier. However, the observed response rate of $34.8 \%$ in patients with a disease-free interval of $<1$ year shows that the use of taxanes in this specific population also represents a valid option. Furthermore, as we received information of approximately $30 \%$ of the target population, a selection bias cannot be ruled out.

The response rate of tumor phenotypes according to hormone and HER2 receptor status was not significantly different; however, the rate was highest in HER2-positive tumors (being treated additionally with an anti-HER2 agent). Surprisingly, triple-negative tumors usually considered to be highly resistant to palliative chemotherapy showed a response rate as high as $50 \%$. This is in line with data with anthracyclines and taxanes as neoadjuvant therapy, with a high pathologic complete response rate [26, 27].

The re-challenge of taxanes at a later line resulted in a much lower response rate; however, these patients were heavily pretreated. Due to the small number and the wide heterogeneity of this population, the only firm conclusion that can be drawn from this cohort study is that a third use of taxanes does not seem to result in a clinical benefit for the patient (even with a good response at first line) and should be avoided.

Re-challenging taxane as first- or later-line treatment for patients with recurrent disease after (neo-)adjuvant taxanebased chemotherapy appears to be a reasonable option, also for patients with triple-negative tumors.

\section{Disclosure Statement}

This project received unrestricted funding by Sanofi-Aventis, Germany. 


\section{References}

1 Conlin AK, Seidman AD: Taxanes in breast cancer: an update. Curr Oncol Rep 2007;9:22-30.

2 Eniu A, Palmieri FM, Perez EA: Weekly admin istration of docetaxel and paclitaxel in metastatic or advanced breast cancer. Oncologist 2005;10:665685.

3 Perez EA: Paclitaxel in breast cancer. Oncologist 1998:3:373-389.

4 Jackisch C, Untch M, Chatsiproios D, et al.: Breast cancer: analysis of treatment quality in Germany 2004: retrospective survey by Arbeitsgemeinschaft Gynäkologische Onkologie (AGO). Zentralbl Gynakol 2006;128:352-361.

5 Diagnosis and treatment of patients with primary and metastatic breast cancer. Recommendations of the Breast Commission of the Working Group Gynaecologic Oncology. www.ago-online.de/index php? lang = en and site $=$ mamma_guide_topical and topic $=$ mamma_guide .

6 von Minckwitz G, Raab G, Caputo A, et al.: Doxorubicin with cyclophosphamide followed by docetaxel every 21 days compared with doxorubicin and docetaxel every 14 days as preoperative treatment in operable breast cancer: the GEPARDUO study of the German Breast Group. J Clin Oncol 2005;23:2676-2685.

7 von Minckwitz G, Blohmer JU, Raab G, et al.: In vivo chemosensitivity-adapted preoperative chemotherapy in patients with early-stage breas cancer: the GEPARTRIO pilot study. Ann Oncol 2005;16:56-63.

8 von Minckwitz G, Kummel S, Vogel P, et al.: Intensified neoadjuvant chemotherapy in early-responding breast cancer: phase III randomized GeparTrio study. J Natl Cancer Inst 2008;100:552-562.

9 von Minckwitz G, Kummel S, Vogel P, et al.: Intensified neoadjuvant chemotherapy in early-responding breast cancer: phase III randomized GeparTrio study. J Natl Cancer Inst 2008;100:552-562.

10 von Minckwitz G, Rezai M, Loibl S, et al.: Capecitabine in addition to anthracycline/taxanebased neoadjuvant treatment in patients with primary breast cancer: the phase III GeparQuattro study. J Clin Oncol 2010;28:2015-2023.
11 Untch M, Rezai M, Loibl S, et al.: Neoadjuvant treatment with trastuzumab in HER2-positive breast cancer: results from the GeparQuattro study. J Clin Oncol 2010;28:2024-2031.

12 Untch M, Fasching PA, Konecny GE, et al.: PREPARE trial. A randomized phase III trial comparing preoperative, dose-dense, dose intensified chemotherapy with epirubicin, paclitaxel and CMF versus a standard dosed epirubicin/cyclophosphamide followed by paclitaxel \pm darbepoetin alfa in primary breast cancer - results at the time of surgery. Ann Oncol, in press.

13 Untch M, von Minckwitz G, Konecny GE, et al.: PREPARE trial. A randomized phase III trial comparing preoperative, dose-dense, dose intensified chemotherapy with epirubicin, paclitaxel and CMF versus a standard dosed epirubicin/cyclophosphamide followed by paclitaxel \pm darbepoetin alfa in primary breast cancer - outcome on prognosis. Ann Oncol, in press.

14 Untch M, Fasching PA, Konecny GE, et al.: Pathological complete response after neoadjuvant chemotherapy plus trastuzumab predicts favorable survival in HER2-overexpressing breast cancer Results from the TECHNO trial of the AGO and GBG study groups. J Clin Oncol, in press.

15 Loibl S, Mueller V, von Minckwitz G, et al.: Comparison of pegfilgrastim on day 2 vs. day 4 as primary prophylaxis of intense dose-dense chemotherapy in patients with node-positive primary breast cancer within the prospective, multi-center GAIN study: (GBG 33). Support Care Cancer, in press.

16 von Minckwitz G, Costa SD: Docetaxel (Taxotere $^{\circledR}$ ) zur Therapie des Mammakarzinoms. Höchste Wirksamkeit bei moderaten Nebenwirkungen. Med Klin 1997;92(suppl IV):4-9.

17 Chan S, Friedrichs K, Noel D, et al.: Prospective randomized trial of docetaxel versus doxorubicin in patients with metastatic breast cancer. J Clin Oncol 1999;17:2341-2354.

18 Nabholtz JM, Falkson C, Campos D, et al.: Docetaxel and doxorubicin compared with doxorubicin and cyclophosphamide as first-line chemotherapy for metastatic breast cancer: results of a randomized, multicenter, phase III trial. J Clin Oncol 2003;21:968-975.
19 Marty M, Cognetti F, Maraninchi D, et al.: Randomized phase II trial of the efficacy and safety of trastuzumab combined with docetaxel in patients with human epidermal growth factor receptorpositive metastatic breast cancer administered as first-line treatment: the M77001 study group. J Clin Oncol 2005;23:4265-4274.

20 Nabholtz JM, Mackey JR, Smylie M, et al.: Phase II study of docetaxel, doxorubicin, and cyclophosphamide as first-line chemotherapy for metastatic breast cancer. J Clin Oncol 2001;19:314-321.

21 Nabholtz JM, Gelmon K, Bontenbal M, et al. Multicenter, randomized comparative study of two doses of paclitaxel in patients with metastatic breast cancer. J Clin Oncol 1996;14:1858-1867.

22 Seidman AD, Berry D, Cirrincione C, et al. Randomized phase III trial of weekly compared with every-3-weeks paclitaxel for metastatic breast cancer, with trastuzumab for all HER-2 overexpressors and random assignment to trastuzumab or not in HER-2 nonoverexpressors: final results of Cancer and Leukemia Group B protocol 9840. J Clin Oncol 2008;26:1642-1649.

23 Gianni L, Munzone E, Capri G, et al.: Paclitaxel by 3-hour infusion in combination with bolus doxorubicin in women with untreated metastatic breast cancer: high antitumor efficacy and cardiac effects in a dose-finding and sequence-finding study. J Clin Oncol 1995;13:2688-2699.

24 Slamon DJ, Leyland-Jones B, Shak S, et al.: Use of chemotherapy plus a monoclonal antibody against HER2 for metastatic breast cancer that overexpresses HER2. N Engl J Med 2001;344:783-792.

25 Rivera E, Gomez H: Chemotherapy resistance in metastatic breast cancer: the evolving role of ixabepilone. Breast Cancer Res 2010;12(suppl 2):S2.

26 Huober J, von Minckwitz G, Denkert C, et al.: Effect of neoadjuvant anthracycline-taxane-based chemotherapy in different biological breast cancer phenotypes: overall results from the GeparTrio study. Breast Cancer Res Treat 2010;124:133-140.

27 Liedtke C, Mazouni C, Hess KR, et al.: Response to neoadjuvant therapy and long-term survival in patients with triple-negative breast cancer. J Clin Oncol 2008;26:1275-1281. 